\title{
The Sober Revolution
}





\title{
The Sober Revolution
}

Appellation Wine and the Transformation of France

\author{
Joseph BoHLing
}

Cornell University Press ITHACA AND LONDON 
Copyright $@ 2018$ by Cornell University

All rights reserved. Except for brief quotations in a review, this book, or parts thereof, must not be reproduced in any form without permission in writing from the publisher. For information, address Cornell University Press, Sage House, 512 East State Street, Ithaca, New York 14850. Visit our website at cornellpress.cornell.edu.

First published 2018 by Cornell University Press

Printed in the United States of America

Library of Congress Cataloging-in-Publication Data

Names: Bohling, Joseph, 1978- author.

Title: The sober revolution : appellation wine and the transformation of France / Joseph Bohling.

Description: Ithaca : Cornell University Press, 2018. I Includes bibliographical references and index.

Identifiers: LCCN 2018015873 (print) | LCCN 2018016576 (ebook) | ISBN 9781501716058 (epub/mobi) | ISBN 9781501716065 (pdf) |

ISBN 9781501716041 I ISBN 9781501716041 (cloth; alk. paper)

Subjects: LCSH: Wine industry-France-History-20th century. I

Wine and wine Making-Marks of origin-France-History-20th century.

Classification: LCC HD9382.5 (ebook) I LCC HD9382.5 .B64 2018

(print) I DDC 338.4/76632009440904—dc23

LC record available at https://lccn.loc.gov/2018015873

Cover illustration: "Plaisir de boire, ne dure qu'un moment!" ["The pleasure of drinking only lasts a moment!"] HCEIA (Haut comité d'étude et d'information sur l'alcoolisme) poster, c. 1955-1960. Courtesy of the National Archives of France, Pierrefitte-sur-Seine. 
To my family,

for loving me absolutely 
